Article

\title{
Intraclade Contact from an I-Language Perspective. The Noun Phrase in the Ligurian/Occitan amphizone
}

\author{
Diego Pescarini
}

check for

updates

Citation: Pescarini, Diego. 2021.

Intraclade Contact from an

I-Language Perspective. The Noun

Phrase in the Ligurian/Occitan

amphizone. Languages 6: 77. https://

doi.org/10.3390/languages6020077

Academic Editors: Ángel Gallego,

Bruno Camus, Ricardo Etxepare, Iván

Ortega-Santos, Francesc Roca, Juan

Uriagereka, Greta Mazzaggio, Juana

M. Liceras and Raquel

Fernández Fuertes

Received: 27 January 2021

Accepted: 12 April 2021

Published: 21 April 2021

Publisher's Note: MDPI stays neutral with regard to jurisdictional claims in published maps and institutional affiliations.

Copyright: (C) 2021 by the author. Licensee MDPI, Basel, Switzerland. This article is an open access article distributed under the terms and conditions of the Creative Commons Attribution (CC BY) license (https:/ / creativecommons.org/licenses/by/ $4.0 /)$.

\author{
CNRS, Université Côte d'Azur, BCL, 06357 Nice, France; diego.pescarini@univ-cotedazur.fr
}

\begin{abstract}
This article aims to compare some traits that characterise the syntax of the noun phrase in the Occitan/Ligurian amphizone (i.e., contact area) that lies at the border between southern France and northwestern Italy. The dialects spoken in this area differ in several syntactic traits that emerged in a situation of contact between dialects of different subgroups (Ligurian and Occitan), two roofing languages (Italian and French), and regional contact languages such as Genoese. In particular, I will elaborate on the syntax of mass and indefinite plural nouns, on the co-occurrence of determiners and possessives, and on the syntax of kinship terms. From an I-language perspective, the fine variation observed at the Occitan/Ligurian border raises two types of research questions: (a) which comparative concepts best capture the observed variation; (b) whether intraclade contact (i.e., contact between languages of the same branch) can contribute relevant evidence and arguments to the debate concerning the biological endowment of the language faculty.
\end{abstract}

Keywords: syntax; morphology; dialects; Romance; agreement

\section{Introduction}

This article intends to discuss the relevance of dialectological data to the current debate on linguistic contact. I will focus on contact between genealogically related dialects that, although belonging to the same linguistic branch (clade), are separated by a bundle of isoglosses. I will, therefore, deal with intraclade contact-i.e., contact between linguistic varieties that are geographically and genealogically close-and not with interclade contact, i.e., contact between separate clades of the phylogenetic tree. Interclade contact is a window into our I-language, allowing us to study how competing grammars interact in the linguistic competence of bilingual speakers. By contrast, the relevance of intraclade contact from an I-language perspective is far less clear and, to the best of my knowledge, whether data from dialectology may play a role in the current debate on contact is a research question that has not been addressed properly. This article intends to tackle this issue by building on a case study regarding some aspects of the syntax of the determiner phrase (DP) in the contact area between Occitan and Ligurian dialects that are spoken at the border between northwest Italy and southeast France.

The case study in Section 2 focuses primarily on the syntax of the noun/determiner phrase in Nissart (Niçart/Niçois), the Occitan dialect spoken in the city of Nice (southern France). ${ }^{1}$ I will compare Nissart with nearby linguistic systems that are attested in the contact area (amphizone, in the traditional dialectological terminology ${ }^{2}$ ) stretching from the River Var (immediately west of Nice; see Figure 1d) to the Italian town of Taggia.

1 For helpful comments on a previous version of this work, I wish to thank Michèle Oliviéri, Sylvain Casagrande, Philippe Del Giudice, Cristina Guardiano, the participants to the SLE workshop 'Contact and the architecture of language faculty' organised by Rita Manzini and Greta Mazzaggio (27 August 2020), the audience of the linguistic seminar of the University of Modena and Reggio Emilia, and two anonymous reviewers.

2 See Petracco Sicardi and Azaretti (1989). 


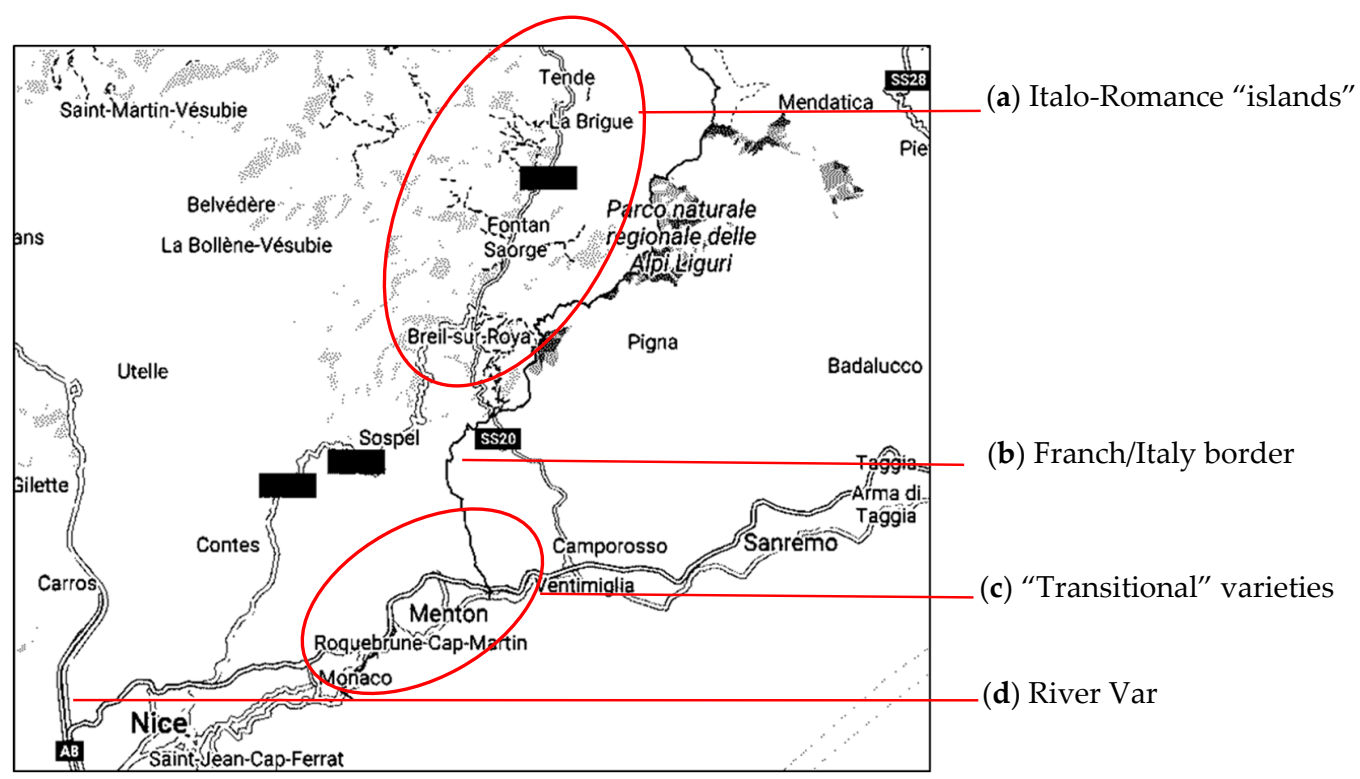

Figure 1. Contact area between southern Occitan and (Intemelian) Ligurian. Source: Google Maps.

The dialects spoken in this area belong to two Romance subgroups: southern Occitan (Sauzet and Oliviéri 2016) and Intemelian Ligurian (Forner 1986). The linguistic boundary between Occitan and Italo-Romance, unlike the one between Italian and French, runs nowadays through French territory (Figure 1b; see Dalbera 2003): Italo-Romance dialects are still spoken in the French villages of Saorge, Breil-sur-Roya, Fontan, Brigue, and Tende (see Figure 1a). Conversely, no Occitan dialect is spoken in Liguria, although few municipalities at the border claim their dialect is Occitan. From a sociolinguistic standpoint, Italian speakers tend to be diglossic (Italian/dialect), whereas French speakers tend to be monolingual. Occitan varieties and the Ligurian dialects in French territory are, in fact, highly endangered.

Conservative traits are better preserved in the mountain areas or in the rustic registers of the coastal vernaculars, which have been influenced by Genoese, the transregional contact language up until the 19th century. Linguistic boundaries are therefore more nuanced along the coast, especially in the "transitional" area around Menton (Figure 1c) ${ }^{3}$.

In terms of roofing languages ${ }^{4}$, the whole area has witnessed the influence of both Italian and French. Until the second half of the 19th century, Italian was spoken, at least by the upper class, in the counties of Nice and Savoy, which in 1860 were given to France by Sardinia-Piedmont in return for Napoleon III's support in the war against Austria. In the same period, French was spoken and written by the elites of the kingdom of Piedmont. Nowadays, the linguistic boundary between Italian and French coincides with the administrative border and, except daily commuters, the linguistic communities at the border-namely in the towns of Menton and Ventimiglia-are not bilingual.

Phonological, morphological, lexical, and syntactic isoglosses separate southern Occitan and Ligurian dialects. Most studies have examined this contact/transition area with the intent of providing a sound classification (Forner 1986, 1989; Dalbera 1994, 2003). Syntax has been examined cursorily and only with respect to well-known distinctive characteristics such as those summarised in Table 1 (Forner 1986, p. 163; Oliviéri 2009):

- Southern Occitan dialects are null-subject languages that do not exhibit subject clitics, unlike northern Italo-Romance dialects such as Ligurian;

- In the Nice region (Alpes-Maritimes), object clitics always precede infinitives;

3 Dialects spoken around Menton are difficult to classify, but see (Oliviéri 2009).

4 A "roofing language" (Dachsprache, Kloss 1967) is the linguistic variety that serves as a standard language in a linguistic community in which other dialects are spoken. 
- Dative clitics follow object ones (a trait that characterises the most western Ligurian dialects as well).

Table 1. Syntactic differences between eastern Occitan and western Ligurian dialects. The symbols + and - signal the presence vs. absence of the properties listed in the first column.

\begin{tabular}{lccc}
\hline & Nissart & Intemelian Ligurian & Other Ligurian Dialects \\
\hline Subject clitics & - & + & + \\
\hline Enclisis to infinitives & - & + & + \\
\hline Dat $>$ Acc clitics & - & - & + \\
\hline
\end{tabular}

This study intends to provide a microcomparative analysis of selected varieties, focusing on some aspects of the syntax of the determiner phrase (DP). The DP has proved to be a reliable proxy for linguistic classification: by using syntactic parameters as comparanda for historical investigation, Longobardi and Guardiano (2009); Guardiano et al. (2016) show that the clusters of languages generated by a principled, theory-informed analysis of the DP correspond to the linguistic families and groups reconstructed on the basis of non-syntactic evidence. Although the case study in Section 2 has a mainly descriptive character, works such as Longobardi and Guardiano (2009) and Guardiano et al. (2016) show that some facets of nominal syntax are symptomatic of higher-grade parameters of syntactic variation.

The description of Nissart is based on a corpus of 20th century texts (as previously said, most dialects in the French territory are almost extinct) and novel data obtained from semi-speakers. Data are stored in the Nice-based database Thesoc ${ }^{5}$. For cross-linguistic comparison with Occitan and Italo-Romance systems, the study relies on data from linguistic atlases such as $\mathrm{ALF}^{6}$, $\mathrm{AIS}^{7}$, and $\mathrm{ASIt}^{8}$ and the material published in Manzini and Savoia (2005).

The article is organised as follows: Section 2 overviews the morphosyntactic traits that characterise the vernaculars spoken in the amphizone (e.g., the syntax of articles and possessives, also in combination with kinship terms); Sections 3 and 4 discuss how the data overviewed in Section 2 may contribute to two possible streams of research. Section 3 illustrates the role of closely related languages in order to fine-tune comparative concepts, i.e., theoretical constructs that allow linguists to align data from different linguistic systems in contact; Section 4 concludes by elaborating on the role of intraclade contact in the current debate on contact within an I-language perspective. To anticipate my conclusions, I will argue that, at first sight, contact in the dialectological sense has little to offer to scholars working within an I-language perspective and/or with experimental methods. Under closer scrutiny, however, data such as those presented in Section 2 may still be relevant, albeit indirectly, for two reasons. First, they show that complex patterns of variation are always reducible to discrete, binary options $(+/-)$ : at the microsyntactic level, continuous variables and/or free variation are both excluded. Second, a fine-grained microcomparative analysis allows us to single out linguistic traits that are prone to be borrowed by neighbouring languages; in this respect, the study of "transitional" dialects can possibly corroborate (or challenge) analogous observations arising from the analysis of bilingual productions.

http:/ / thesaurus.unice.fr/ (accessed on 14 April 2021).

ALF maps have been downloaded from the website of the SYMILA project: http:/ / symila.univ-tlse2.fr/ (accessed on 14 April 2021).

7 I consulted the online version of the atlas, Navigais (Tisato 2010): https:/ /www3.pd.istc.cnr.it/navigais-web/ (accessed on 14 April 2021). AIS transcriptions can be downloaded from the website of the project AIS, reloaded: https://www.ais-reloaded.uzh.ch/ (accessed on 14 April 2021).

8 http://asit.maldura.unipd.it/ (accessed on 14 April 2021). 


\section{Case Study: Aspects of DP Syntax}

In the following subsections, Nissart will be taken as a touchstone for the comparison with nearby dialects. With the exception of Section 2.1 (which focuses entirely on the morphology of Nissart), the following subsection first presents an overview of the Nissart data and then deals with the linguistic patterns found in other Occitan and western Ligurian varieties.

\subsection{Morphology of Nissart Nominal Elements}

To better understand the syntactic data in the subsections that follow, I overview here the morphology of nouns and nominal modifiers in Nissart (Gasiglia 1984).

Definite articles and demonstratives (plus three adjectives; more on this below) are the sole nominal elements that exhibit a four-way number/gender inflection, as shown in Table 2.

Table 2. Paradigm of Nissart definite articles.

\begin{tabular}{ccc}
\hline & SG & PL \\
\hline$M$ & $1(\mathrm{ou})[\mathrm{lu}]$ & $\mathrm{lu}[\mathrm{ly}]>\%$ li, cf. (1) \\
\hline $\mathrm{F}$ & $1(\mathrm{a})$ & $\mathrm{li}$ \\
\hline
\end{tabular}

In the spoken language, the form $l i$ is seldom used as a syncretic form for both masculine and feminine plural nouns (see (1)). Whether the change in the form of the mpl definite article (from [ly] to [li]) is caused by endogenous or exogenous motivations (e.g., contact with French) remains an open question as the few attestations of $<\mathrm{li}>$ in the corpus appear to be randomly distributed.
(1) e cadun si passegia souta li aubre. ${ }^{9}$ and everybody self= walk under the tree.MPL
'and everybody walks under the trees.'

Nissart has three series of demonstratives, see Table 3: proximal, medial, and distal. Each form can be used either as a determiner or as a pronoun. Demonstratives agree like articles:

Table 3. Paradigm of demonstratives.

\begin{tabular}{lcccc}
\hline & MSG & MPL & FSG & FPL \\
\hline Proximal & (aic)estou & (aic)estu & (aic)esta & (aic)esti \\
\hline Medial & aquestou & aquestu & aquesta & aquesti \\
\hline Distal & aquèu/-el & aquelu & aquela & aqueli \\
\hline
\end{tabular}

Possessives fall into three types: postnominal agreeing possessives as in (2)a, prenominal non-agreeing possessives as in (2)b and agreeing prenominal possessives that are used in combination with kinship nouns as in (2)c. The latter are in complementary distribution with determiners. Unlike articles and demonstratives, possessives exhibit a pattern of agreement in which masculine singular and plural endings are syncretic (see Table 4).

(2) a. la cadièra mieua (Niss.)

$$
\text { 'my seat' }
$$

b. la mieu(*a) cadièra

'my seat'

c. ma tanta

my aunt

\footnotetext{
9 From La Ratapignata, July 1935 (Lucile Mockers p.c.).
} 
Table 4. Paradigm of Nissart possessives.

\begin{tabular}{cccc}
\hline Possessor & Postnominal & Prenominal & before Kinship Ns \\
\hline & $($ M $/$ FSG $/ \mathrm{FPL})$ & $($ M $/$ FSG $/ \mathrm{FPL})$ & $($ MSG $\sim$ FSG $)$ \\
\hline 1 & miéu- $\varnothing / \mathrm{a} / \mathrm{i}$ & miéu & moun $\sim$ ma \\
\hline 2 & tiéu- $\varnothing / \mathrm{a} / \mathrm{i}$ & tiéu & toun $\sim$ ta \\
\hline $3 / 6$ & siéu- $\varnothing / \mathrm{a} / \mathrm{i}$ & siéu & soun $\sim$ sa \\
\hline 4 & nouòstr-e/a/i & nouòstr-e/a/i & nouòstr-e $/ \mathrm{a}$ \\
\hline 5 & vouòstr-e/a/i & vouòstr-e/a $/ \mathrm{i}$ & vouòstr-e/a \\
\hline
\end{tabular}

Adjectives occur either prenominally or postnominally, with the same orders and interpretations we find in other Romance languages such as French and Italian: quality and size adjectives can precede (object-denoting) nouns, while adjectives denoting shape, colour and nationality must follow the noun; the interpretation of adjectives that can occur either before or after the noun changes according to their position; when combined, classes of adjectives are rigidly ordered unless they are modified. No morphological difference distinguishes prenominal from postnominal adjectives, although asymmetries of this kind are attested in other Occitan dialects (Pomino and Stark 2009 and references therein). Regular adjectives of the first class display the same agreement system as postnominal possessives, in which masculine singular and plural forms are syncretic, see Table 5.

Table 5. Paradigm of adjectives of the first class, e.g., brave "good".

\begin{tabular}{ccc}
\hline & SG & PL \\
\hline$M$ & brave & brave \\
\hline$F$ & brava & bravi \\
\hline
\end{tabular}

Three adjectives differ from the others in having different forms for the masculine singular and plural. These endings, however, do not correspond to those of determiners:
a. bèu/l, bei, bella, belli (Niss.)
'nice.msg, $\sim \mathrm{mpl}, \sim \mathrm{fsg}$, $\sim \mathrm{fpl}^{\prime}$
b. bouòn, bouòi, bouòna, bouòni 'good.msg, $\sim \mathrm{mpl}, \sim \mathrm{fsg}, \sim \mathrm{fpl}$ '
c. pichoun, picoui, pichouna, pichouni 'little.msg, $\sim \mathrm{mpl}, \sim \mathrm{fsg}, \sim \mathrm{fpl}^{\prime}$

Nouns normally do not display number inflection: singular and plural nouns have the same ending, both in the masculine and in the feminine. The majority of feminine nouns, for instance, end in $-a$ in the singular and in the plural. As a result, number is clearly marked only on determiners, on the irregular adjectives in (3), on feminine adjectives as shown in (4), and on postverbal possessives.

(4) a. la bella filha. (Niss.)

'the nice girl.'

b. li belli filha.

'the nice girls.'

The agreement mismatch between determiners, feminine adjectives, and nouns yields an asymmetry in the marking of number that recalls patterns of so-called lazy concord/agreement (Sauzet 2012; for an overview of lazy concord, see Pomino and Stark 2009). In Nissart, however, the asymmetry takes place regardless of the ordering and interpretation of nominal constituents. Only possessives are involved in a synchronically active alternation between agreeing and non-agreeing forms (cf. (2)a vs. (2)b; more on this in Section 2.2). 
Table 6 provides an overview of the agreement endings of nouns (deriving from the Lat. 1st declension), adjectives (of the first group), and other nominal modifiers. Cases of syncretism are marked in grey:

Table 6. Inflectional endings.

\begin{tabular}{cccccc}
\hline & ART & DEM & POSS & ADJ1 & N1 \\
\hline MSG & $\mathrm{u}$ & $\mathrm{u}$ & $\mathrm{u}$ & $\mathrm{e}$ & - \\
\hline MPL & $\mathrm{y}>\mathrm{i}$ & $\mathrm{y}>\mathrm{i}$ & $\mathrm{u}$ & $\mathrm{e}$ & $\mathrm{a}$ \\
\hline FSG & $\mathrm{a}$ & $\mathrm{a}$ & $\mathrm{a}$ & $\mathrm{a}$ & $\mathrm{a}$ \\
\hline FPL & $\mathrm{i}$ & $\mathrm{i}$ & $\mathrm{i}$ & $\mathrm{i}$ & $\mathrm{a}$ \\
\hline
\end{tabular}

Having introduced some basic facts concerning agreement in Nissart, we can now address syntactic phenomena. The subsections that follow describe first the main features of Nissart, which are then compared with data from nearby Occitan and Ligurian dialects.

\subsection{Article-Less NPS}

In Nissart, mass singulars and indefinite plurals are always introduced by de (without an article, unlike French in (5) $a^{\prime}$ and (5) $\left.b^{\prime}\right)$ :

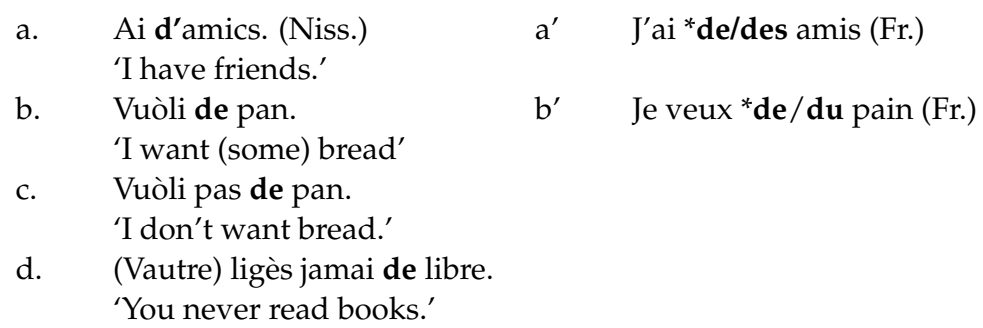

So called partitive articles, i.e., determiners formed by the preposition de plus the definite article (e.g., $d e+l o u \rightarrow d o u$ ), are marginally attested in Nissart. The conditions under which partitive articles occur are not completely clear to me, due to the scarcity of examples in my corpus, which may also contain calques from French. Gasiglia (1984) suggests that partitive articles are restricted to cases of nominal ellipsis of the kind illustrated in (6)c, but the hypothesis needs further testing. ${ }^{10}$

(6) a. Vouòli *dou vin. (Niss)

'I want (some) wine.'

b. Vouòli *dou vin rouge.

'I want (some) red wine.'

c. Vouòli dou rouge

'I want (some) red wine.'

Bare mass singulars and indefinite plurals, even if introduced by $d e$, are marginal in subject position, where indefinite nouns are usually introduced by a dummy definite article as in (7)a. ${ }^{11}$ In this respect, noun phrases introduced by $d e$ are subject to the same restriction as bare nouns in a language such as Italian (Longobardi 1994).

$\begin{array}{llllllll}\text { (7) a. } & \mathrm{l}^{\prime} & \text { aiga } & \text { es } & \text { venguda } & \text { de } & \text { la } & \text { fouònt. (Niss.) } \\ & \text { the } & \text { water } & \text { is } & \text { come } & \text { from the } & & \text { fountain } \\ \text { b. } \quad{ }^{2} \mathrm{~d}^{\prime} & \text { aiga } & \text { es } & \text { venguda } & \text { de } & \text { la } & \text { fouònt } \\ & \text { of } & \text { water } & \text { is } & \text { come } & \text { from the } & & \text { fountain } \\ \text { c. }{ }^{*} \mathrm{de} \mathrm{l}^{\prime} & \text { aiga } & \text { es } & \text { venguda } & \text { de } & \text { la } & \text { fouònt } \\ & \text { of the } & \text { water } & \text { is } & \text { come } & \text { from the } & & \text { fountain }\end{array}$

\footnotetext{
10 Hopefully, fieldwork with elderly speakers—which, until now, has been impossible due to the current pandemic situation—will help us to ascertain the conditions licensing partitive articles and the diffusion of the phenomenon in nearby Occitan and Ligurian dialects (more on this below).

11 Article-less NPs can occur in subject position in proverbs. The same holds true for other Romance languages such as French and Italian.
} 
Bare NPs are, therefore, systematically ruled out in Nissart. As an anonymous reviewer pointed out, Nissart is consistent with Delfitto and Schroten's (1991) hypothesis according to which the lack of bare NPs in languages such as French correlates with the absence of number morphology on the noun. Recall that number morphology in Nissart is not marked on nouns (see Table 6). ${ }^{12}$ Data on other Occitan areas, reported in Sauzet (2014, pp. 2-3) and summarized in Table 7, bring further confirmation to Delfitto and Schroten's (1991) generalization as dialects lacking plural morphology on Ns never allow bare plurals.

Table 7. Licensing of indefinite plurals vs. number morphology on Ns in Occitan varieties (data from Sauzet 2014, pp. 2-3).

\begin{tabular}{cccc}
\hline Example & Area & D & N-pl \\
\hline Que mingi [p'uməs] & Gsc., Fuxean Leng. & $\varnothing$ & $-s$ \\
\hline Mangi [de p'uməs] & Lengadocian & $d e$ & $-s$ \\
\hline Mange [de p'umə] & Provençal & $d e$ & $\varnothing$ \\
\hline Mange [de la: puma:] & Lemosin & $d e+$ art & $\varnothing$ \\
\hline I mange [d la pumaj] & Marchés & $d e+$ art & $-j$ \\
\hline
\end{tabular}

Certain indefinite plurals, mainly pluralia tantum such as li bràia ("trousers"), li aisamenta ("dishes"), are introduced by the indefinite article uni, e.g., uni bràia "a pair of arms" (Gasiglia 1984, p. 118), which-morphologically—seems a plural form derived from the indefinite pronoun $u n$ "a". According to Ledgeway (2016, p. 765), however, similar forms that are attested in other Romance areas (see (8)) are "best considered indefinite quantifiers rather than plural articles since-unlike the corresponding singular articlesthey generally prove optional".

(8) a. Había unas caxes enriba la mesa. (Ast.)

'there.were some boxes on the table'

b. Fau unas còcas. (Lgd.)

'I.make some cakes'

Having introduced the main features of Nissart, let us compare the Nissart system with nearby dialects. With respect to other Occitan dialects, Sauzet (2014, p. 2) offers a thorough overview of how mass nouns and plural indefinites are licensed in Occitan. He shows that Occitan dialects exploit three strategies: southern Gascon and southwestern Occitan dialects allow bare nouns (see (9)c), Lemosin and northern Occitan dialects require partitive articles (i.e., NPs that are introduced by $d e+$ article, cf. (9)b), whereas in central and south-eastern Occitan dialects, including Nissart, NPs are introduced by de:

(9) a. Que mingi Ø sopa/pan/higas/melons. (Southern Gascon, SW Occitan)

b. Minge de la sopa/del (dau) pan/de las figas/dels melons. (Lemosin N Occ.) 'I eat soup/bread/figs/melons.'

c. Mangi de pan e bevi d'aiga. (Lengadocian or Central Occ., Provençal E Occ.) 'I eat bread and drink water.'

According to the data in the ALF (see Figure 2; the relevant data are reported in Table 8), in the linguistic area surrounding Nice (Alpes-Maritimes), mass singulars and plural indefinites are introduced by de (without article) in the dialects that are situated west of Nice such as Plan-du-Var (898) and Le Cannet (897). Conversely, the Ligurian dialect of Fontan (990) and the "transitional" dialect of Menton (899) differ from other southern Occitan varieties in requiring the definite article after $d e:^{13}$

12 Certain suffixed feminine nouns are noticeable exceptions (see Gasiglia 1984, p. 117), which however do not contradict Delfitto and Schroten's claim.

13 Notice that this coincides with the lexical isogloss argent/soldi "money". 


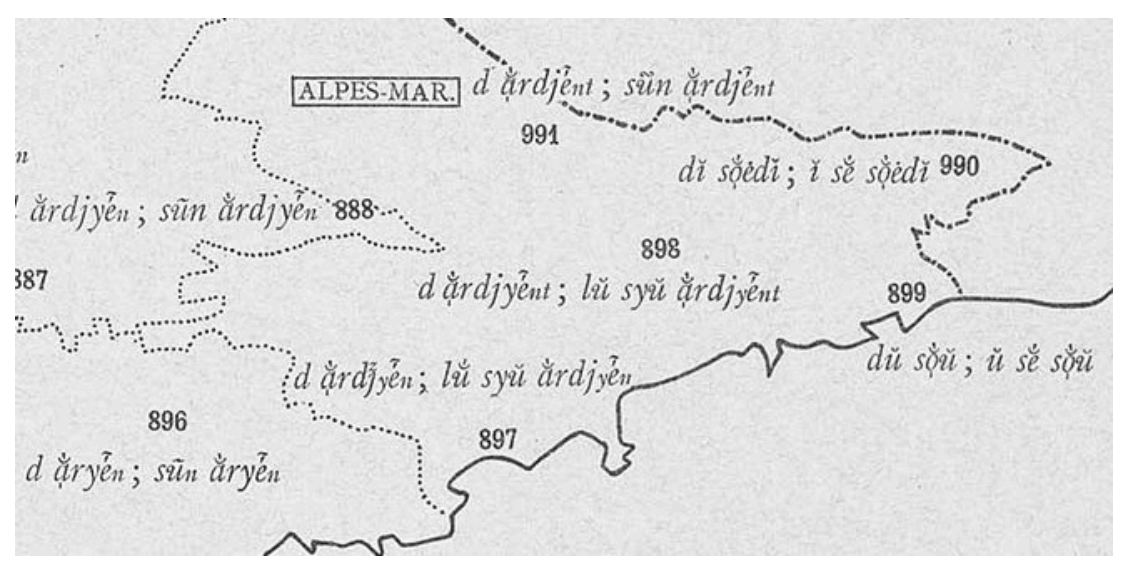

Figure 2. ALF 57: (gagner) de l'argent; ( . . et que nous lui rendions) son argent. The map shows how mass nouns are licensed (before the semicolon) and whether possessives co-occur with articles (after the semicolon).

Table 8. Summary of relevant data from ALF 57: (to gain) money; Fr. (gagner) de l'argent; with a simplified transcription.

\begin{tabular}{cc}
\hline Datapoint & Dialect Translation \\
\hline Plan-du-Var (898) & $\ldots$ d ardjye $\mathrm{nt}_{\mathrm{t}}$ \\
\hline Le Cannet (897) & $\ldots$ d ardj $\mathrm{e}_{\mathrm{n}}$ \\
\hline Fontan (990) & $\ldots$ di sòedi \\
\hline Menton (899) & $\ldots$ du sòu \\
\hline
\end{tabular}

Fontan and Menton (among the so-called transitional varieties) exhibit the same system as Ligurian and Piedmontese dialects that are spoken in Italy. According to the data reported in the AIS, the latter always require mass nouns to be introduced by de plus the definite article (for a systematic overview of the AIS data, see Cardinaletti and Giusti 2018).

In negative clauses, however, (western) Ligurian dialects require article-less phrases introduced by de, as in French (Garzonio and Poletto 2018). The comparison between Nissart/southern Occitan dialects and Ligurian with respect to the marking of plural indefinite and singular mass nouns is summarised in Table 9.

Table 9. Marking of plural indefinite and singular mass nouns.

\begin{tabular}{cccc}
\hline & Nissart & Transitional Varieties & Ligurian \\
\hline POSITIVE & $d e$ & $d e+$ art & $d e+$ art \\
\hline NEGATIVE & $d e$ & NA & $d e$ \\
\hline
\end{tabular}

\subsection{Possessives: Co-Occurrence with $D$ and Agreement}

In Nissart, possessives co-occur with definite and indefinite articles (except possessives introducing kinship nouns, cf. Section 2.4):

(10) a. Alu nouastre primou pas en la vida. (Niss.)

'to.our first step in life.'

b. Lou miéu libre.

'my book.'

c. Li nouastri cansoun.

'our songs.'

(11) Un siéu libre. (Niss.)

'A book of his/hers/theirs.' 
According to the data in Figure 2 (reported in Table 10), the co-occurrence of articles and possessives sets apart the dialects of the Alpes-Maritimes such as Nissart, Plan-du-Var (AIS 898) and Le Cannet (AIS 897) from the other Occitan dialects such as Seillans (AIS 896) and Puget-Théniers (888), where articles and possessives do not co-occur. Possessives and articles always co-occur in the nearby western Ligurian dialects.

Table 10. Summary of relevant data from ALF 57: (we will give him) his money; Fr. (lui rendions) son argent; with a simplified transcription.

\begin{tabular}{cc}
\hline Datapoint & Dialect Translation \\
\hline Seillans (896) & $\ldots$ sun arjye $_{\mathrm{n}}$ \\
\hline Puget-Théniers (888) & $\ldots$ su $_{\mathbf{n}}$ arye $_{\mathrm{n}}$ \\
\hline Plan-du-Var (898) & $\ldots$ lu syu ardj $_{\mathrm{y}} \mathrm{e}_{\mathrm{nt}}$ \\
\hline Le Cannet (897) & $\ldots$ lu syu ardj $\mathrm{e}_{\mathrm{n}}$ \\
\hline Fontan (990) & $\ldots$ i se sòedi \\
\hline Menton (899) & $\ldots$ u se sòu \\
\hline
\end{tabular}

Postnominal possessives are necessarily focalised (Cardinaletti 1998) and, unlike prenominal possessives, they can be modified and coordinated (although the coordination and modification of postnominal possessives are always perceived as unnatural and are, therefore, hard to elicit).

(12) a. ??Li cadièra miéui e tiéui. (Niss.)

b. $\quad *$ Li cadièra miéu e tiéu.

'The chairs of mine and yours.'

Postnominal possessives are identical to predicative possessives and possessive pronouns, which are always preceded by the definite article, as shown in (13)a' (Gasiglia 1984, p. 164):

(13) a.

\begin{tabular}{|c|c|c|c|c|c|c|c|}
\hline $\begin{array}{l}\text { Aqueu } \\
\text { That }\end{array}$ & $\begin{array}{l}\text { libre } \\
\text { book }\end{array}$ & $\begin{array}{l}\text { es } \\
\text { is }\end{array}$ & $\begin{array}{l}\text { miéu } \\
\text { my }\end{array}$ & $a^{\prime}$. & $\begin{array}{l}\ldots \text { es } \\
\ldots \text { is }\end{array}$ & $\begin{array}{l}\text { lou } \\
\text { the }\end{array}$ & $\begin{array}{l}\text { miéu (Niss.) } \\
\text { mine }\end{array}$ \\
\hline \multicolumn{8}{|c|}{ 'That book is mine' } \\
\hline $\mathrm{Li}$ & maious & soun & miéui & & & & \\
\hline The & sweaters & are & my.pl & & & & \\
\hline \multicolumn{8}{|c|}{ 'The sweaters are mine' } \\
\hline $\mathrm{La}$ & fauta & es & pas & nouòstra. & & & \\
\hline The & mistake & is & not & our.fsg & & & \\
\hline
\end{tabular}

Monosyllabic prenominal possessives (miéu, tiéu, siéu) do not agree in gender and number, whereas first- and second-person plural possessives—-that are disyllabic—always agree:
a. la mieu(*a) cadièra
vs. $a^{\prime}$.
la nouòstr*(a) cadièra (Niss.)
'my chair'
'our chair'
b. li mieu(**i) cadièra
vs. $\quad b^{\prime}$. li nouòstr*(i) cadièra
'my chairs'
'our chairs'

Non-agreeing prenominal possessives are found in Ligurian as well, as shown in Table 11, which compares singular and plural DPs ${ }^{14}$ in dialects from the westernmost Ligurian provinces (Savona and Imperia). In this respect, microvariation is really pervasive as systems with and without agreement are geographically scattered, as is expected in mountain areas such as the Ligurian inland:

14 Unfortunately, most atlases contain data on possessives only in combination with kinship terms. However, whereas singular kinship nouns are peculiar (as they normally occur in article-less DPs), plural kinship nouns behave syntactically like all other nouns (more on this in Section 2.4) in requiring a determiner even if a prenominal possessive is present. 
Table 11. Possessives in singular and plural DPs (Source: ASIt). Inflected forms are in bold.

\begin{tabular}{ccc}
\hline 'Your Friend' & 'Your Sons' & Dialect \\
\hline$U$ to amisc & I toj fieuj & Altare \\
\hline$U$ to $\ldots{ }^{15}$ & I toi fiej & Cairo Montenotte \\
\hline$U$ to amigu & I to fioi & Calizzano \\
\hline NA & I to fioi & Carcare \\
\hline$U$ to amigu & I to fio & Finale Ligure \\
\hline$U$ to amiz & I toi fioi & Pontinvrea \\
\hline NA & I to figio & Savona \\
\hline NA & I toi fiöi & Taggia \\
\hline$U$ tou amigu & I toi fioi & Vallecrosia \\
\hline$U$ toh amisc & I toj fieuj & Altare \\
\hline NA & I toi fiej & Cairo Montenotte \\
\hline
\end{tabular}

To summarise, Nissart displays a dedicated series of possessives that introduce kinship nouns and are in complementary distribution with articles (cf. Section 2.4). The other possessives, by contrast, can co-occur with the definite article and are free to occur prenominally, postnominally, and in predicative position. In Nissart, prenominal monosyllabic possessives do not agree. ${ }^{16}$ The latter trait is found in some, but not all dialects of western Ligurian (see Table 11).

\subsection{Possessives with Kinship Terms}

As previously mentioned, Nissart exhibits a dedicated series of possessives occurring with kinship terms. The possessives that occur with kinship nouns are in complementary distribution with definite articles.

$$
\begin{aligned}
& \text { a. 'moun paire. (Niss.) } \\
& \text { b. vou dad' } \\
& \text { vouòstra souòrre } \\
& \text { 'your sister' } \\
& \text { c. sa mougliè } \\
& \text { 'his wife' }
\end{aligned}
$$

Such possessives are restricted to singular, non-modified nouns. Plural and modified kinship nouns are introduced by articles and "plain" possessives (Gasiglia 1984, p. 168): ${ }^{17}$

(16) a. ( $\left.{ }^{*} \mathrm{lou}\right)$ toun ouncle/lu tiéu ouncle (Niss.)

'your uncle/your uncles'

b. (*la) vouòstra tanta/li vouòstri tanta 'your aunt/your aunts'

c. $\quad\left({ }^{*} \mathrm{lou}\right)$ soun fraire/lu siéu fraire 'his/her brother/his/her brothers.'

(17) a. lou miéu vielh paigran. (Niss.) 'my old grandfather'

b. la miéu paura souòrre 'my poor sister'

15 Parry (2005, p. 160)

16 The lack of agreement on prenominal possessives resembles patterns of asymmetric/"lazy" agreement, which normally targets adjectives, depending on their prenominal or postnominal placement. Lazy concord is quite frequent in Romance and is attested in some varieties of Occitan (cf. Pomino and Stark 2009 and references therein), but—crucially—not in Nissart.

17 According to Philippe Del Giudice (p.c.), the article is not obligatory with modified kinship nouns. If the article is dropped, the form of the possessive remains unchanged. 
Many Romance languages, including western Ligurian dialects, exhibit similar restrictions, although they do not display dedicated possessives for kinship terms. For instance, plural kinship nouns are introduced by articles in the dialect of Pigna, as shown in (18) $\mathrm{c}^{\prime}-\mathrm{d}^{\prime}$ (Manzini and Savoia 2005, III: 660ff): ${ }^{18}$
a. $\mathrm{m} \varepsilon \mathrm{i} / \mathrm{t} \varepsilon \mathrm{i} / \mathrm{s} \varepsilon \mathrm{i}$ 'po (Pigna)
'my/your/his/her dad'
b. $\mathrm{mia} / \mathrm{ta} / \mathrm{sa} \mathrm{mp}$
'my/your/his/her mum'
c. $\mathrm{m} \varepsilon \mathrm{i} / \mathrm{t} \varepsilon \mathrm{i} / \mathrm{s} \varepsilon \mathrm{i}$ 'fi $\mathrm{Ku}$
'my/your/his/her son'
d. $\mathrm{mia} / \mathrm{ta} / \mathrm{sa}$ 'fiKa
'my/your/his/her daughter'

\author{
$c^{\prime} . \quad$ i mei/tzi/sci fiKei \\ 'my/your/his/her sons' \\ d'. e mie/tue/sue 'fiKe \\ 'my/your/his/her daughters'
}

The dialects of the amphizone exhibit noticeable variation with respect to agreement in possessives. In Occitan, including Nissart, and in certain Ligurian dialects such as Pigna in (18) and Vallecrosia in (19), possessives agree in gender with kinship nouns:
to barba, to frai
'your uncle, your
vs. ta so, ta maire (Vallecrosia)
'your uncle, your brother'
'your sister, your mother'

By contrast, the vast majority of western Ligurian dialects display uninflected possessives (see Table 12).

Table 12. Possessives with masculine vs. feminine kinship nouns in Ligurian dialects (Source: ASIt).

\begin{tabular}{ccc}
\hline 'Your Uncle' & 'Your Sister' & Dialect \\
\hline to barba & to seu & Altare \\
\hline to barba & to surella & Cairo Montenotte \\
\hline to barba & to so & Calizzano \\
\hline to barba & to so & Carcare \\
\hline to borba & to so & Finale Ligure \\
\hline to barba & to so & Pontinvrea \\
\hline to barba & to so & Savona \\
\hline to barba & to sö & Taggia \\
\hline
\end{tabular}

To conclude, the syntax of kinship nouns shows that Occitan and Ligurian dialects exhibit some common features (possessives have a "special syntax" when combined with singular, non-modified kinship terms) and some differences regarding the morphology. Two main parameters seem relevant to capture the observed variation: syncretism and agreement.

With the term "syncretism", I refer to the fact that the possessives used with kinship terms are identical to "plain" prenominal possessives (and differ from postnominal ones). In this respect, Nissart and a Ligurian dialect such as Cairese (Parry 2005, pp. 160-63) exhibit different patterns of syncretism, see Table 13: in the former, possessives with kinship nouns form a separate class from other possessives, which have the same "root" (modulo agreement); in the latter, all prenominal possessives look alike and differ from postnominal possessives.

18 The data reported in the AIS, however, show that not all Ligurian dialects exhibit the pattern in (18). The dialect of Airole, for instance, systematically differs from the nearby datapoint (Borgomaro) as the former tends to lack articles with both singular and plural kinship terms. The AIS data, which were collected at the beginning of the 20th century, seem to suggest that cross-linguistic variation was more kaleidoscopic than it is nowadays as, in most recent surveys, I cannot find traces of bare plural kinship nouns. It is probable that the influence of Italian, in which plural kinship nouns must always occur with the article, obliterated some fine-grained microvariation. 
Table 13. Comparison between possessives with kinship nouns vs. other nouns. Grey cells contain syncretic elements.

\begin{tabular}{cccc}
\hline & Kinship N & Prenominal & Postnominal \\
\hline Nissart & ta & tiéu & tiéu- $a$ \\
\hline Cairese (Lig.) & to & to & tua \\
\hline
\end{tabular}

The second parameter at play is agreement, see Table 14: certain dialects such as Pignasco exhibit agreeing forms in all positions, others such as Cairese exhibit non-agreeing forms in all prenominal positions; Nissart stands out because prenominal monosyllabic possessives cannot bear agreement endings, except those introducing kinship terms.

Table 14. The possessives form "your" with kinship nouns vs. other nouns. Grey cells contain non-agreeing forms.

\begin{tabular}{cccc}
\hline & Kinship N & Prenominal & Postnominal \\
\hline Nissart & toun (FSG ta) & tiéu & tiéu (FSG tiéu-a) \\
\hline Pigna (Lig.) & tei (FSG ta) & tєi (FSG ta) & NA \\
\hline Cairese (Lig.) & to & to (MPL toj) & toj (FSG tua) \\
\hline
\end{tabular}

Syncretism and agreement are expected to combine, yielding a rich range of possible systems. In fact, it seems to me that only the patterns in Tables 13 and 14 are attested. We therefore expect syntactic theory to explain why actual systems are a subset of the expected ones. I will resume this point in Section 3, which focuses on the analysis of possessive-marking with kinship nouns.

\section{5. (Interim) Conclusions}

Table 15 compares the data discussed so far regarding the realization of indefinite mass and plural nouns and that of possessives. I examined three main phenomena: (a) the realization of $d e$ with mass and plural nouns; (b) the distribution and morphological properties of possessives; (c) possessive-marking with kinship nouns.

As for (a), eastern Occitan differs from Ligurian in requiring article-less DPs introduced by $d e$ (notice that the dialects of the so-called transitional area exhibit partitive articles like in Ligurian). The distinction between the two linguistic groups is obliterated in negative environments, where nouns are always introduced by $d e$.

As for (b), the dialects of the Nice area resemble Ligurian: unlike the other Occitan dialects, they permit determiners and possessives to co-occur. Prenominal possessives in Nissart and certain Ligurian dialects do not agree in gender and/or in number.

As for (c), the dialects of the amphizone show the Italo-Romance system, in which non-modified kinship nouns do not allow the co-occurrence of possessives and articles. Nissart is the sole dialect that exhibits a dedicated series of possessives for kinship terms. Agreement gives rise to further variation: gender and number agreement is neutralized in prenominal monosyllabic possessives in Nissart, but not with kinship terms. Conversely, in most Ligurian dialects, the possessive forms that are subject to neutralization are those found with kinship terms. 
Table 15. Comparison between linguistic areas. The symbols + and - signal the presence vs. absence of the properties listed in the first column; NA means that I do not have enough data to draw a solid conclusion.

\begin{tabular}{lccccc}
\hline & & Occitan & & \multicolumn{2}{c}{ Ligurian } \\
\hline & E. Occ. ${ }^{19}$ & Nissart & Trans. & Intemelian & Others \\
\hline a. Article-less indefinite plural and mass Ns & & & & \\
\hline bare N (like It.) & - & - & - & - & NA \\
\hline$d e+$ N in positive clauses & + & + & - & - & - \\
\hline$d e+$ N in negative cl. & + & + & + & + & + \\
\hline$b$. Possessives (no kinship Ns) & & & & & + \\
\hline Article + possessives & - & + & + & + & + \\
\hline Postnominal possessives & NA & + & + & + & + \\
\hline Agreement & NA & - & NA & + & + \\
\hline c. Possessives with kinship Ns & & & & & + \\
\hline Article with pl. Ns & - & + & NA & + & + \\
\hline Same as poss. in (b) & + & - & NA & + & - \\
\hline Agreement & + & + & + & $+/-$ & + \\
\hline
\end{tabular}

The kind of variation described in Table 15 (and Table 1) is far from surprising, at least from the point of view of geo-linguistic/E-language contact. In the following section, I will try to elaborate on the results summarized in Table 15 to discuss whether such kind of data may contribute to a better understanding of contact from an I-language perspective.

\section{Fine-Tuning Comparative Concepts: The Case of "Clitic" Possessives}

This section focuses on the behaviour of possessives introducing kinship terms; cf. Section 2.4 and section (c) of Table 15. The languages of the amphizone exhibit a uniform syntactic behaviour: in all dialects, possessives are in complementary distribution with articles when DPs are headed by a singular, non-modified kinship noun. The morphology of possessives, on the contrary, is subject to variation with respect to two parameters: (1) Nissart exhibits a dedicated series of possessives for kinship terms, while in the other Occitan and Ligurian dialects, all prenominal possessives belong to a single series; (2) in Occitan, Nissart, and some Ligurian dialects, the possessive forms that introduce kinship nouns agree in gender (e.g., Niss. moun vs. ma "my"), whereas in other Ligurian dialects (as well as in many northern Italian dialects), prenominal possessives do not agree, in particular in gender; in general, possessives introducing kinship terms tend to agree less than other prenominal possessives (cf. Table 11 vs. Table 12 in Section 2.4).

Ideally, one aims to capture this kind of fine-grained variation in compliance with principles of theoretical parsimony, i.e., Occam's razor. In particular, we aim to adopt comparative concepts that, on the one hand, capture similarities between languages that are genealogically unrelated (or are situated far from each other in the phylogenetic tree) and, on the other hand, account in an elegant way for minimally different languages.

To account for microvariation and similarities in possessive systems, Cardinaletti (1998) and Cardinaletti and Giusti (2018) propose a three-way distinction of possessive modifiers based on Cardinaletti and Starke's (1999) model of functional classes. According to Cardinaletti and Starke, function words belong to at least three classes, depending on their degree of structural deficiency. The typology is illustrated in (19) with data from

19 The label E(astern) Occ(itan) refers to the Occitan dialects close to the amphizone. As an anonymous reviewer pointed out, the situation in other Occitan varieties can be very heterogeneous. 
Paduan (Paduan is a northern Italian dialect spoken in the Veneto region, far from the Occitan/Ligurian amphizone):

- $\quad$ Strong possessives do not move from their base-generation position and, being fully fledged XPs, they can be coordinated, focalised, modified, etc.; in languages with $\mathrm{N}$ movement, they occur postnominally as in (19)a.

- Weak possessives move to a prenominal position; see (19)b.

- Clitic possessives move to D; they are therefore in complementary distribution with articles and may allow doubling (see (19)c); in many Romance languages, clitic possessives are restricted to kinship nouns.

$\begin{array}{llllll}\text { a. } & \text { el } & \text { libro } & \text { suo. } & \text { Strong } & \text { (Paduan) } \\ \text { b. } & \text { the } & \text { book } & \text { his } / \text { her } & & \\ \text { el } & \text { so } & \text { libro. } & \text { Weak } & \\ \text { the } & \text { his/her } & \text { book } & & \\ \text { c. } & \text { so } & \text { mama } & \begin{array}{l}\text { (de Giani). } \\ \text { his/her }\end{array} & \text { Clitic } & \\ & \text { mum } & \text { of Gianni } & \end{array}$

In Cardinaletti's 1998 analysis, clitic possessives are first merged as possessive modifiers and eventually cliticised to the Determiner position D, after being stripped of their external layers of structure:

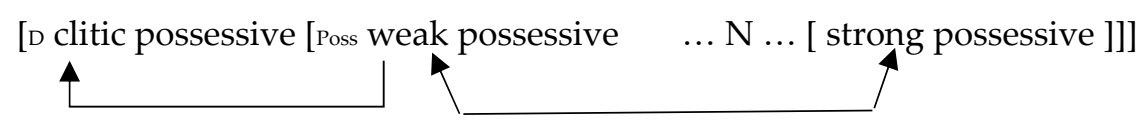

Apparently, Nissart fits perfectly into Cardinaletti's classification. As previously mentioned, Nissart possessives fall into three types: postnominal agreeing possessives, prenominal non-agreeing possessives and clitic possessives. Like in Paduan, clitic possessives occur with singular kinship nouns and are in complementary distribution with determiners.

$\begin{array}{lll}\text { a. la cadièra mieua. } & \text { Strong } & \text { (Niss.) } \\ \text { b. } \quad \begin{array}{l}\text { 'my seat' } \\ \text { la } \text { mieu(*a) cadièra. }\end{array} & \text { Weak } \\ \text { 'my seat' } & \text { Clitic } \\ \text { c. ma tanta. } & \end{array}$

Under closer scrutiny, however, it seems to me that the concept "clitic possessive" does not provide a sensible analysis of Nissart and improves neither the comparison with other dialects of the amphizone, nor the comparison with other Gallo-Romance systems (Cardinaletti's view has already been challenged by French data, see Ihsane 2000; Bernstein 2005). In the remainder of this section, I will therefore try to revise the notion of "clitic possessive".

Clitic possessives, in Cardinaletti's 1998 classification, are characterized by two properties: they are in complementary distribution with determiners and may allow doubling, as shown in (22).

(22) a. son père à lui / ... à Jean. (French; Thsane 2000: fn. 15) 'his father to him/J.'.

$\begin{array}{llll}\text { b. } \quad \text { ta } & \text { maison } & \text { à } & \text { toi. } \\ \text { your } & \text { house } & \text { to } & \text { you } \\ \text { 'your own house.' } & & & \end{array}$

Doubling, however, is not a necessary condition, as clitic doubling is subject to language-specific restrictions. The fact that Nissart, unlike Paduan in (19)c, does not allow doubling is not per se evidence against Cardinaletti's classification: 
(23)

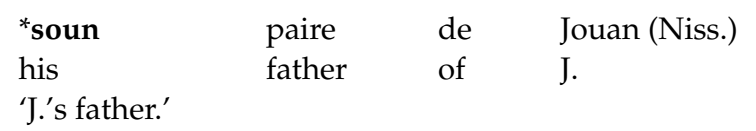

In absence of doubling, the real hallmark of clitic possessives is their incompatibility with determiners. The problem, in my opinion, is that this incompatibility does not necessarily follow from the supposed clitic status of possessives. First of all, it is not clear to me what prevents the formation of clitic clusters formed by determiners and possessives, in the same way in which subject and object clitics can be combined to form complex clitic chains.

By the same token, it is not clear to me why possessives cannot climb to verbs, like bona fide clitic elements do in the same languages/dialects: ${ }^{20}$

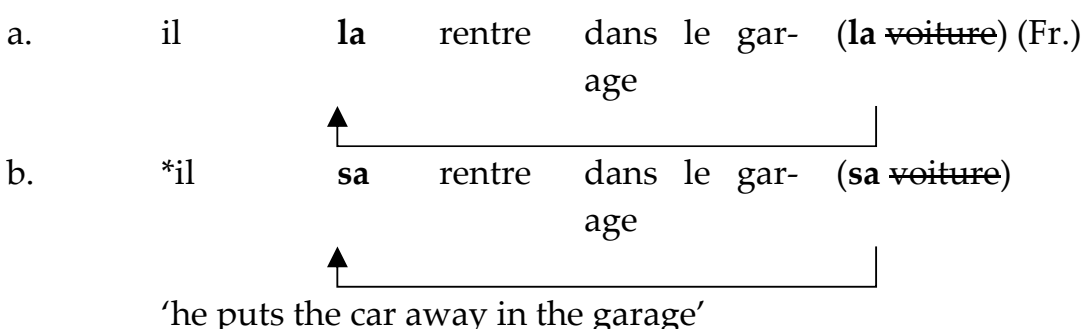

Moreover, it is not clear to me why possessives cannot cliticise to an indefinite (null) D. In principle, nothing prevents clitic possessives from yielding an indefinite reading, but in fact, this is not the case: so-called clitic possessives are inherently definite:

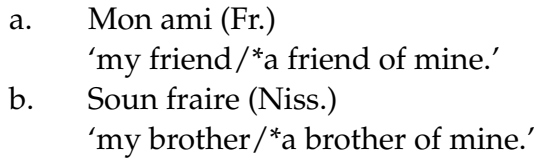

Further evidence for the inherently definite nature of (so-called) clitic possessives comes from the extraction of dative clitic possessives. In French, this construction is limited to datives of inalienable possession (Vergnaud and Zubizarreta 1992), whereas possessors of other kinds are necessarily encoded in D. Conversely, in Nissart and ItaloRomance-i.e., in languages with adjective-like prenominal possessives-possessors of any kind can be extracted from definite and indefinite DPs regardless of the nature of the possessor/possessed relationship:

\begin{tabular}{|c|c|c|c|c|c|c|}
\hline a. & $\begin{array}{l}\text { On } \\
\text { one }\end{array}$ & $\begin{array}{l}\text { lui } \\
\text { to.him }\end{array}$ & $\begin{array}{l}\text { a } \\
\text { has }\end{array}$ & $\begin{array}{l}\text { volé } \\
\text { stolen }\end{array}$ & $\begin{array}{l}{ }^{\%} \mathbf{l a} / \mathbf{s a} \\
\text { the/his }\end{array}$ & $\begin{array}{l}\text { chaise. } \\
\text { chair }\end{array}$ \\
\hline b. & $\begin{array}{l}\mathbf{L i} \\
\text { to.him= }\end{array}$ & $\begin{array}{l}\text { an } \\
\text { they.have }\end{array}$ & $\begin{array}{l}\text { roubat } \\
\text { stolen }\end{array}$ & $\begin{array}{l}\text { la } \\
\text { the }\end{array}$ & $\begin{array}{l}\text { (siéu) } \\
\text { his }\end{array}$ & $\begin{array}{l}\text { cadièra. } \\
\text { chair }\end{array}$ \\
\hline c. & $\begin{array}{l}\text { Gli } \\
\text { to.him= }\end{array}$ & $\begin{array}{l}\text { hanno } \\
\text { they.have }\end{array}$ & $\begin{array}{l}\text { rubato } \\
\text { stolen }\end{array}$ & $\begin{array}{l}\text { la } \\
\text { the }\end{array}$ & $\begin{array}{l}\text { (sua) } \\
\text { his }\end{array}$ & $\begin{array}{l}\text { sedia. } \\
\text { chair }\end{array}$ \\
\hline
\end{tabular}

The unavailability of the indefinite reading with clitic possessives and the fact that clitic possessives are necessarily merged in D means that French-like possessives are not clitic or impoverished counterparts of the adjectival possessives of the Nissart type. Rather, French possessives and-mutatis mutandis—the series of possessives occurring with kinship nouns in Nissart instantiate a particular type of definite determiner (see Longobardi and Guardiano's (2009) “D-checking possessive" (see also Guardiano et al. 2016, 2018). Hence, possessives of the French type (and, arguably, the possessives we find with kinship nouns

20 One may argue that possessives can climb, yielding dative of possession, cf. (25). However, datives of possession are often marginal or ungrammatical precisely in the languages and contexts where clitic possessives are expected to occur (more on this below). 
in other Romance languages) are D elements that agree in person with the so-called possessor. ${ }^{21}$ They might be morpho-phonologically clitic, but clitichood per se does not account for their behaviour.

Further evidence for this analysis comes from agreement in Nissart. As previously mentioned, so-called "weak" prenominal possessives in Nissart do not agree, whereas so-called clitic possessives agree in gender. The agreement pattern of Nissart is at odds with a Cardinaletti-style analysis such as (27), in which weak prenominal possessives are obtained when the outer layer of strong (postnominal) possessives peels off. Since the only morphological difference between prenominal "weak" and postnominal "strong" possessives concerns agreement, one may conclude that the agreement layer is stripped away when the possessive moves from its base-generation position. However, the fact that clitic possessives agree in gender (like postnominal possessives) contradicts this conclusion: as a matter of fact, "clitic" possessives are less impoverished than their "weak" counterparts, contra the model in (27).

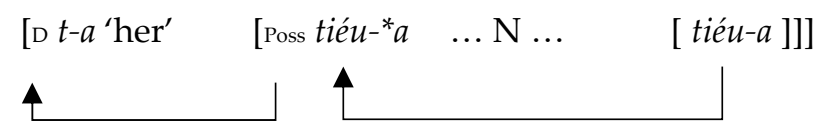

In conclusion, although Nissart possessives seem to fit perfectly into Cardinaletti and Starke's (1999) three-way typology, I tried to show that none of the properties of so-called clitic possessives results from their supposed clitic nature. Instead, by comparing Nissart and French, I suggested that so-called clitic possessives are better analysed as definite determiners, regardless of their clitic or non-clitic status.

Another property that the hypothesis of clitic possessives cannot account for is the asymmetry between plural and singular kinship nouns. Recall that in Nissart, like in Italian and in many northern Italo-Romance dialects, only singular, non-modified kinship nouns co-occur with clitic possessives. Why would plurality or modification prevent possessives from being merged in D? Giusti (2015) claims that rigid designators such as proper names and kinship nouns project a reduced DP $\mathrm{n}$ which no Functional Projection occurs between $\mathrm{D}$ and N. Unlike proper names, kinship nouns select an argument in N's thematic field, which needs to be overtly realized. When the argument of kinship nouns is realized by a possessive, it must be merged in $\mathrm{D}$ as no intermediate position is available between $\mathrm{N}$ and D. However, if other layers of structure are added to the reduced DP (to merge modifiers or express plurality), the DPs must be "extended" regardless of the presence of a kinship noun; possessives can then be harboured between the article and the noun.

In my opinion, Giusti's (2015) theory that kinship nouns project a reduced DP is on the right track as it yields interesting predictions about the realization of possessives when it is coupled with the hypothesis that certain possessives are in fact $\mathrm{D}$ elements, as proposed above. Three possible systems are then envisaged:

- $\quad$ Languages in which possessives are D elements (Gallo-Romance, except Nissart).

- Languages in which possessives are not D elements (Italo-Romance, including standard Italian); in reduced DPs (i.e., with non-modified kinship nouns), possessives move to D as proposed by Giusti (2015). This explains why, in these languages, "weak" and "clitic" possessives have the same exponent as in Cairese; cf. Table 13, or Paduan in (19).

- $\quad$ Languages with a double series of pronominal possessives (Nissart): D possessives and adjective-like possessives; the former occur in reduced DPs, the latter-which are akin to postnominal possessives-occur in extended DPs, where they co-occur with determiners.

21 In my opinion, possessor agreement is better conceived of as a case of Restrictor Agreement in the sense of Ackema and Neeleman (2018, p. 179), i.e., Person features on the possessors do not result from a Probe-Goal relation, but "function as restrictors on a variable that is introduced by this element and subsequently associated with the apparent controller". 
An approach like this can explain why certain languages exhibit a dedicated series of possessives for kinship terms, whereas in others all preverbal possessives have the same shape, regardless of the presence/absence of the determiner. From a geolinguistic point of view, it is worth noting that languages of the third type such as Nissart are spoken in the contact area between languages with and without D possessives (Gallo-Romance and Italo-Romance, respectively).

\section{Discussion: Intraclade Contact from an I-Language Perspective}

Building on the data in Section 2, this section intends to discuss two related points:

(a) Whether an I-language perspective can shed light on the nature of amphizones;

(b) Whether (and to what extent) intraclade contact of the kind documented in Section 2 is relevant for a model of I-language.

I anticipate that, while an I-language perspective may lead us to a better understanding of the mechanisms at play in so-called transitional areas, the contribution of dialectological data to the I-language perspective remains less clear to me. Section 4.2 contains some tentative considerations and suggestions for further research.

\subsection{I-Language and the Nature of Amphizones}

I used the term amphizone to refer to areas of transition between languages that belong to the same branch (clade), but differ in several linguistic respects. In the Ligurian/Occitan amphizone, for instance, variants are separated by a bundle of isoglosses that emerged because physical and political barriers hindered the transmission of innovative traits from one side to the other, thus yielding a fracture in the linguistic continuum. Although this fracture is perceivable by everyday speakers, it does not preclude mutual intelligibility.

The idea that contact played a pivotal role in determining how dialects are grouped dates back to the 19th century, when the predominant scientific paradigm in dialectology was the theory of layers (strata) ${ }^{22}$. According to this view, present-day differences reflect the influence of the languages spoken before the Latinization (substratum), of the languages that were/are spoken at the boundary of the Romance area (adstratum), or of the high/roofing languages that co-exist with dialects in contexts of diglossia (superstratum). Linguistic differentiation emerged from situations of asymmetric bilingualism, leading either to borrowing from one stratum to another or to a generalized impoverishment of the Latin grammar due to attrition.

Concretely, what are the possible effects of other linguistic layers on the Occitan/Ligurian continuum? With respect to the data in Section 2, attrition of the substratum can be safely excluded because all the traits summarized in Tables 1 and 15-clitics and determiners-are innovations that emerged in the Middle Ages. One might suggest that contact with roofing languages (French or Italian) may have triggered recent changes such as the neutralization of gender distinctions in plural determiners in Nissart, e.g., fpl [li], mpl [ly] > [li] "the" (cf. Section 2.1). At a more abstract level, I argued in Section 3 that Nissart has a double series of possessives: D possessives like French and adjectival-like possessives like ItaloRomance. One might claim that the co-existence of two series of possessives resulted from an influence of the roofing language (French) on an underlying Italo-Romance system. All these hypotheses are difficult to test, but what is crucial for our discussion is that this kind of explanation cannot account for most of the fine-grained variation illustrated in Section 2.

Given the nature, distribution and chronology of microphenomena (at all levels, syntactic, morphological, phonetic, lexical, etc.), the strata hypothesis needs to be tempered. Hugo Schuchardt (1842-1927; see, for instance, Schuchartd 1870) was the first to propose a more nuanced model of change and variation, by arguing that the Romance area is a linguistic continuum and that differences resulted from several waves of innovations that

22 The theory of strata is often attributed to the Italian linguist Graziadio Isaia Ascoli (1829-1907), in particular in relation to his studies on the classification of Italo-Romance dialects. However, Ascoli never gave a systematic illustration of the theory-this is why it is so difficult to find a precise reference on the topic-but rather assumed and exploited ideas that had already been circulating at the time. 
spread in multiple directions across space and time. The kind of theory envisaged by Schuchardt was revived in 20th century sociolinguistic approaches in which endogenous change results from contact between dialects (i.e., sociolinguistic varieties) within the same language (see Milroy (1992, p. 88) a.o.). Notice that, in the latter view, languages are conceived as a social construct, whereas the strata hypothesis is rooted in a Darwinian approach, in which languages are seen as living entities, independent from the community of speakers.

I do not intend to elaborate further on the long-lasting debate about layers vs. waves, but what is relevant for our purposes is that the two approaches to language diversity presuppose two very different conceptions of contact. In the former (layers), contact refers mainly to the coexistence of languages that are unrelated or belong to distinct branches of the phylogenetic tree (interclade contact, according to my terminology) and presupposes two conditions that are not necessarily met in intraclade contact: bilingualism and borrowing. In fact, speakers from an amphizone are not necessarily dialect/dialect bilingual (or bidialectal). Nowadays, most speakers acquire both their local dialect and a roofing language (either Italian or French), but they do not acquire two dialects belonging to, e.g., the Occitan and the Italo-Romance subgroups ${ }^{23}$. Leaving roofing languages aside, it is questionable whether speakers of the past have ever learnt more than a local dialect. I mentioned in Section 1 that some 19th century speakers of the Riviera were able to communicate in Genoese, which has been the contact language of sailors and traders for centuries, but I doubt that inhabitants of inland centres ever learnt the dialect of their neighbours as in fully fledged contexts of bilingualism. Dialect speakers probably adapted their E-language in the same way in which speakers shift from a linguistic register to another, depending on the characteristics of the hearer. Avoiding the most local/rural phonetic and lexical features was probably enough to communicate with members of nearby linguistic communities.

Similar considerations hold for the notion of "borrowing". The various linguistic communities that populate the amphizone have evolved in parallel and the similarities we observe nowadays do not result because one language borrowed a given trait from another. For instance, it is unlikely that the co-occurrence of articles and possessives in Nissart is a borrowing from Ligurian (as folk linguists usually suggest). In fact, in the absence of sound historical documentation, one cannot affirm that similarities result from contact-induced change with a nearby variety.

Hence, most features of contact that characterise interclade situations (e.g., bilingualism, attrition, borrowing, etc.) do not seem relevant in intraclade contact. Does this amount to saying that contact is irrelevant for the structural evolution of the varieties in question?

In short, my answer is that, despite intra- and interclade contact result from different conditions, intraclade contact has important effects on the structural evolution of dialects. As Schuchartd (1884, p. 5) put it, "[t]here is no completely unmixed language" and, in rephrasing Schuchardt's intuition, let us assume, following generative theorizing, that syntactic change/variation always results from the transmission (or failures thereof) of linguistic traits across time/space (see Kroch (2001) and references therein). The key notion here is "transmission": I have already argued that the transmission of features in intra- and interclade contact situations follows different paths. Similarities and differences within an amphizone, for instance, did not emerge because adult speakers of one village learnt the language of a neighbouring village and/or failed in learning their neighbours' dialects and ended up with an attrited language. This scenario is highly implausible, given the socio-historical conditions of the area.

Instead, consider that all the dialects spoken in an amphizone emerged from the same language - in our case, a regional variant of vulgar Latin. More technically, varieties emerged via selection of specific features from a common pool of variants: a variant, for instance, regarding how mass singulars and indefinite plurals are introduced, either by

23 As noticed in Section 1, it might be the case that, in the 19th century, mariners from the coastal area were able to speak Genoese. 
$\alpha) d e$ or $\beta) d e+$ Art. Notice that transitional varieties are not those in which both variants are attested. Despite dialects exhibiting fine-grained variation, there is no single variety that exhibits free variation between two alternative variants of the same structure. For instance, with respect to the phenomena illustrated in Table 1, no dialect allows optional subject clitics, or permits either ordering of complement clitics.

Analogously, the dialects of the amphizone do not allow articles and possessives to co-occur optionally: the two types of modifiers are either in complementary distribution or must co-occur. The same holds true for all the other microphenomena overviewed in Section 2 and summarized in Table 15. Hence, isoglosses may overlap, but, once single syntactic traits are examined, we observe that syntactic variation always results from discrete choices and free variation does not really exist.

At the same time, however, it is worth noting that the distribution of two competing variants is never $0 \%$ vs. $100 \%$. For instance, in Section 2.2, we noticed that Nissart adopts $(\alpha)$, although $(\beta)$ is marginally attested in cases of nominal ellipsis of the kind illustrated in (6)c (repeated here as (28)c; Gasiglia 1984).

$$
\begin{array}{ll}
\text { a. } & \text { Vouòli *dou vin. (Niss) } \\
\text { 'I want (some) wine.' } \\
\text { b. } & \text { Vouòli *dou vin rouge. } \\
& \text { 'I want (some) red wine.' } \\
\text { c. } & \text { Vouòli dou vin rouge } \\
& \text { 'I want (some) red wine.' }
\end{array}
$$

Analogously, we observed that the generalization that Nissart prenominal possessives (excluding the D possessives that introduce kinship nouns) do not agree holds true for monosyllabic forms, whereas disyllabic possessives are regularly inflected (cf. $(14)=(29)$ ):

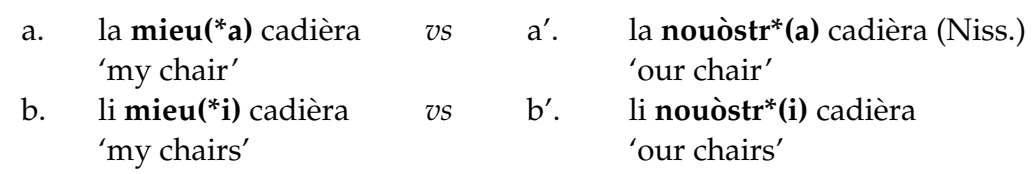

Possessives introducing kinship nouns are another case in point: they are normally found only with non-modified singular kinship terms, but—crucially—-the list of kinship terms occurring in article-less NPs is subject to cross-dialectal variation.

All the above examples show that recessive variants are not expelled from linguistic systems, but remain in the periphery of the grammatical "space": sometimes they are confined to a certain stylistic register or are associated with specific lexical items or to specific pragmatic values. In a scenario like this, surrounding languages are expected to play a role in the selection of linguistic traits to the extent that social contacts affect the number of speakers that, in each community, bear a certain linguistic trait. The higher the number of speakers carrying a given variant $\alpha$, the more likely the possibility that future generations exhibit $\alpha$.

Physical or political barriers, as in the case of the Alpes-Maritimes, hinder social contacts and, consequently, hinder the transmission of variants between communities: recessive features will therefore remain at the periphery of the system, while dominant variants will be passed to new generations. This lack of transmission yields the bundle of isoglosses that, a posteriori, we conceptualize as the amphizone between Occitan and Italo-Romance dialects. Social relations, however, are not completely disrupted and certain localities-in our case, those situated on the coast-exhibit transitional characters. Transitional characters emerge when communities can select their features from a richer pool of variants because the continuous admixture of speakers from various provenance affects the relative incidence of variants: recessive traits can eventually become dominant (or vice versa), depending on either sociolinguistic factors (e.g., prestige) or, possibly, internal factors (more on this in Section 4.2).

To conclude, the conditions yielding intraclade contact differ from those entailed in contexts of interclade contact. Concepts such as bilingualism, attrition, borrowing, etc., are 
rather problematic in the former case. From an I-language perspective, interclade contact presupposes a complex interaction between co-existing grammars, whereas it seems to me that the emergence of transitional varieties through intraclade contact presupposes a less direct role of the faculty of language in the selection of dominant and recessive traits.

\subsection{Is Intraclade Contact Relevant for a Model of I-Language?}

The phenomena described in Section 2 certainly are somehow encoded in the Ilanguage, but I am not sure whether and to what extent these properties reflect an abstract hierarchy of parameters or are to be considered as purely historical accidents that emerged and spread like "cultural artefacts".

The hallmark of parametric variation is the relationship between properties that covariate systematically. A case in point is discussed in Section 2.2, where I mentioned Delfitto and Schroten's (1991) hypothesis that the lack of bare nominal arguments correlates with the absence of number morphology on the noun. Data from Nissart and other Occitan areas confirm the generalization, as dialects lacking plural morphology on Ns do not allow bare plurals:

Since parameters constrain linguistic acquisition, their effects are expected to be particularly clear in transitional areas where, as argued in Section 4.1, traits are selected and recombined more freely than in other linguistic areas. In this respect, amphizones offer nearlaboratory conditions to study parameters as languages belonging to the same linguistic clade allow us to study how certain grammatical features spread from one language to another, all other conditions being equal.

In this respect, I think that two avenues of future research deserve to be explored. First, we expect parameters to have similar effects on both types of contact situations, i.e., interand intra-clade. Second, we expect that the generalizations drawn from different contact areas will ultimately converge. For instance, does the contact area at the Catalan/Occitan border mirror the characteristics we observed in the Occitan/Ligurian amphizone with respect to the syntax of the noun phrase? Are the clusters of phenomena in Table 1 or Table 15 found in analogous contact areas (e.g., southern vs. northern Occitan, or Ligurian vs. Tuscan)? To the best of my knowledge, a comparative analysis of transitional areas has not been pursued yet, but it seems to me that the field is mature in terms of both empirical knowledge and analytical tools.

Funding: This research received no external funding.

Institutional Review Board Statement: Not applicable.

Informed Consent Statement: Not applicable.

Data Availability Statement: Links to publicly archived datasets: Thesoc: http:/ / thesaurus.unice.fr/ (accessed on 14 April 2021); ALF/SYMILA http:/ / symila.univ-tlse2.fr/ (accessed on 14 April 2021); AIS/Navigais https:/ / www3.pd.istc.cnr.it/navigais-web/ (accessed on 14 April 2021); AIS/AIS, reloaded: https:/ / www.ais-reloaded.uzh.ch/ (accessed on 14 April 2021); ASIt: http:/ /asit.maldura. unipd.it/ (accessed on 14 April 2021).

Conflicts of Interest: The author declares no conflict of interest.

\section{References}

Ackema, Peter, and Neeleman, eds. 2018. Features of Person: From the Inventory of Persons to Their Morphological Realization. Cambridge: MIT Press.

Bernstein, Judy B. 2005. On the morpho-syntax of possessive constructions. Recherches linguistiques de Vincennes 34. [CrossRef]

Cardinaletti, Anna. 1998. On the deficient/strong opposition in possessive systems. In Possessors, Predicates, and Movement in the Determiner Phrase. Edited by A. Alexiadou and Ch Wilder. Amsterdam: Benjamins, pp. 17-53.

Cardinaletti, Anna, and Giuliana Giusti. 2018. Indefinite Determiners: Variation and Optionality in Italo-Romance. In Advances in Italian Dialectology. Edited by Roberta D'Alessandro and Diego Pescarini. Boston: Brill, pp. 135-61.

Cardinaletti, Anna, and Michal Starke. 1999. The Typology of Structural Deficiency: A Case Study of the Three Classes of Pronouns. In Clitics in the Languages of Europe. Edited by H. Riemsdijk. Berlin: de Gruyter, pp. 145-233. 
Dalbera, Jean-Philippe. 1994. Les parlers des Alpes Maritimes: étude Comparative, Essai de Reconstruction. Doctoral dissertation, Université Toulouse-Le Mirail, Toulouse, France.

Dalbera, Jean-Philippe. 2003. Les Ilots Liguriens de France. In Les Langues de France. Edited by Bernard Cerquiglini. Paris: Presses Universitaires de France.

Delfitto, Denis, and Jan Schroten. 1991. Bare plurals and the number affix in DP. Probus 3: 155-86. [CrossRef]

Forner, Werner. 1986. À propos du ligurien intémélien-La côte, l'arrière-pays. Travaux du Cercle linguistique de Nice 7-8: $29-62$.

Forner, Werner. 1989. La dialettologia ligure: Risultati e prospettive. In La dialettologiaitaliana oggi. Studi offerti a Manlio Cortelazzo. Edited by Gunter Holtus and Michele Metzeltin e Max Pfister. Tubingen: Narr, pp. 153-78.

Garzonio, Jacopo, and Cecilia Poletto. 2018. Exploiting Microvariation: How to Make the Best of Your Incomplete Data. Glossa: A Journal of General Linguistics 3: 112. [CrossRef]

Gasiglia, Rémy. 1984. Grammaire du Nissart. Nice: Institut d'Études Niçoises.

Giusti, Giuliana. 2015. Nominal Syntax at the Interfaces: A Comparative Analysis of Languages with Articles. Newcastle upon Tyne: Cambridge Scholars.

Guardiano, Cristina, Dimitris Michelioudakis, Andrea Ceolin, Monica-Alexandrina Irimia, Giuseppe Longobardi, Nina Radkevic, Giuseppina Silvestri, and Ioanna Sitaridou. 2016. South by South East. A Syntactic Approach to Greek and Romance Microvariation. L'Italia Dialettale 77: 96-166.

Guardiano, Cristina, Dimitris Michelioudakis, Guido Cordoni, Monica-Alexandrina Irimia, Nina Radkevich, and Ioanna Sitaridou. 2018. Parametric comparison and dialect variation: Insights from Southern Italy. In Romance Languages and Linguistic Theory 14. Selected Papers from the 46th Linguistics Symposium on Romance Languages (LSRL). Edited by Lori Repetti and Francisco Ordóñez. Amsterdam: Benjamins, pp. 10-33.

Ihsane, Tabea. 2000. Three Types of Possessive Modifiers. GG@G 1: pp. 21-54. Available online: http://www.unige.ch/lettres/linge/ syntaxe/journal/volume_one.html (accessed on 15 April 2021).

Kloss, Heinz. 1967. 'Abstand languages' and 'ausbau languages'. Anthropological Linguistics 9: 29-41.

Kroch, Anthony. 2001. Syntactic Change. In The Handbook of Contemporary Syntactic Theory. Edited by Mark Baltin and Chris Collins. Oxford: Blackwell, pp. 699-729.

Ledgeway, Adam. 2016. Functional categories. In The Oxford Guide to the Romance Languages. Edited by Adam Ledgeway and Martin Maiden. Oxford: Oxford University Press, pp. 761-71.

Longobardi, Giuseppe. 1994. Reference and Proper Names: A Theory of N-Movement in Syntax and Logical Form. Linguistic Inquiry 25: 609-65.

Longobardi, Giuseppe, and Cristina Guardiano. 2009. Evidence for Syntax as a Signal of Historical Relatedness. Lingua 119: 1679-706. [CrossRef]

Manzini, Maria Rita, and Leonardo Savoia. 2005. I dialetti italiani e romanci. Alessandria: Dell'Orso.

Milroy, James. 1992. A social model for the interpretation of language change. In History of Englishes: New Methods and Interpretations in Historical Linguistics. Edited by Matti Rissanen, Ossi Ihalainen, Terttu Nevalainen and Irma Taavitsainen. Berlin: De Gruyter, pp. 72-91.

Oliviéri, Michèle. 2009. Frontières linguistiques. In Programme H.O.F. Histoire Orale de la Frontière Constitution d'un Corpus interdisciplinaire de témoignages oraux. Vers une approche pluridisciplinaire en Sciences humaines et sociales dans les vallées de la Roya et de la Bévéra. Edited by Thierry Rosso. Nice: Conseil général des Alpes-Maritimes, pp. 74-84.

Parry, Mair. 2005. Parluma d'Coiri. Sociolinguistica e grammatica del dialetto di Cairo Montenotte. Savona: Società savonese di storia patria.

Petracco Sicardi, Giulia, and Emilio Azaretti. 1989. Studi linguistici sull'anfizona Liguria-Provenza. Alessandria: Edizioni dell'Orso.

Pomino, Natasha, and Elisabeth Stark. 2009. Adnominal adjectives in Romance: Where morphology seemingly meets semantics. In Proceedings of the IV Nereus International Workshop: Definiteness and DP Structure in Romance Languages. Edited by Maria Teresa Espinak, Manuel Leonetti and Louise McNally. Konstanz: Fachbereich Sprachwissenschaft der Universität Konstanz, pp. 113-37.

Sauzet, Patrick. 2012. Occitan Plurals: A Case for A Morpheme Based Morphology. In Inflection and Word Formation in Romance Languages. Edited by Marc-Olivier Hinzelin and Sascha Gaglia. Amsterdam: Benjamins, pp. 179-200.

Sauzet, Patrick. 2014. "Partitives", Number Markingand Negationin Occitan. Talk Given at the International Exploratory Workshop "Partitivity in Romance and Beyond" Zurich, 11-13 December 2014. Available online: https://www.rose.uzh.ch/dam/jcr: fffffff-bbf7-b0bf-0000-000026179556/Sauzet_Partitives_number_negation.pdf (accessed on 15 April 2021).

Sauzet, Patrick, and Michèle Oliviéri. 2016. Southern Galloromance: Occitan. In The Oxford Guide to the Romance Languages. Edited by Adam Ledgeway and Martin Maiden. Oxford: Oxford University Press, pp. 319-49.

Schuchartd, Hugo. 1870. Über die Klassifikation derromanischen Mundarten. (Probevorlesung gehalten zu Leipzig am 30. April 1870). Graz: Styria.

Schuchartd, Hugo. 1884. Slawo-deutsches und slawo-italienisches. Graz: Leuschner \& Lubensky.

Tisato, Graziano. 2010. NavigAIS-AIS Digital Atlas and Navigation Software. In Parlare con le persone, parlare alle macchine: La dimensione interazionale della comunicazione verbale. Atti del VI Convegno Nazionale AISV - Associazione Italiana di Scienze della Voce, Università di Napoli, 3-5-Febbraio 2010. Edited by Francesco Cutugno, Pietro Maturi, Renata Savy, Giovanni Abete and Iolanda Alfano. Rimini: EDK Editore, pp. 451-61.

Vergnaud, Jean-Roger, and Maria Luisa Zubizarreta. 1992. The Definite Determiner and the Inalienable Constructions in French and in English. Linguistic Inquiry 23: 595-652. 